\title{
STATUS UNIVERSITY ART CHARACTER EDUCATION MANAGEMENT SYSTEM AND COUNTERMEASURES
}

Feng Qi, Yan Zhang

Heihe college, Heihe, Heilongjiang, China
*Corresponding Author Email: 305468517@qq.com.

This is an open access article distributed under the Creative Commons Attribution License, which permits unrestricted use, distribution, and reproduction in any medium, provided the original work is properly cited.

\section{ARTICLE DETAILS}

\section{Article History:}

Received 02 october 2017 Accepted 06 october 2017 Available online 11 november 2017

\section{ABSTRACT}

Keywords:

Colleges and universities, art quality education, current situation analysis, countermeasure research, management system
Art quality education in colleges and universities as an integral part of quality education is not only an important way to implement aesthetic education for college students but also a fundamental requirement to promote the all-round development of moral, intellectual and physical education among college students. Through the research on the current situation and countermeasures of art quality education management system, this paper has played an active role in improving the overall quality of students.

\section{Introduction}

The progress and development of human society cannot be separated from the improvement of the quality of human resources. In the fiercely competitive international environment in the 21st century, there is an ever-increasing demand for the all-round development of highly qualified personnel in the society[1,2]. Therefore, on the basis of the old traditional concept of "examination-oriented education" and on the promotion of national qualities and world competition, it is "quality education to create a scientific and effective modern education to promote and improve people's quality and level in an all-round way. education". Artistic quality refers to the comprehensive expression of the ability of appreciation and expression of art. It mainly includes the appreciation, feeling, cognition and expression of music, dance, painting, sculpture, architecture, literature, drama, film and television, etc.

The comprehensive embodiment. Simply put, artistic quality is the ability to feel the United States, appreciate the United States and create the United States. The connotation of artistic quality has the following aspects: First, artistic quality is the unity of artistic cultivation and artistic ability, which is contained within and shaped from the outside. Contained within, is for art conservation; shape is outside, is for artistic ability. Art conservation includes artistic experience, artistic understanding, as well as understanding and mastery of various artistic features; artistic ability includes artistic sensibilities, artistic understanding and artistic creativity. Second: artistic quality with integrity, comprehensiveness and stability [3]. It is not an abstract concept, but a pervasive artistic activity that determines one's entry into a given artistic realm. Therefore, if a person can only perceive an object of art from one aspect, one aspect or one level, or can only appreciate a certain kind of beauty for a certain part of things, then he cannot say that he really possesses the art Quality. Third: art quality is nurtured, with generative and plasticity. Aesthetic awareness and aesthetic awareness are unique spiritual enjoyments of mankind. It is a special psychological activity of people, which is the subjective reflection, feeling, appreciation and evaluation of beauty in art activities. The aesthetic awareness of a person is not an innate ability, but a product of the long-term development of nature and social practice. In the process of transforming the human feeling in society, the feeling of art is confirmed. of course, the quality of art has a physiological basis, its formation depends on the corresponding sensory organs [4]. Innate physical defects, will lead to some aesthetic defects. However, the quality of art is by no means inherited by the world. It is the result of the combined effect of life practice, knowledge cultivation, ideology and other factors.

Fourth: The quality of art is higher than the scientific and moral qualities, is a higher level, more comprehensive quality. Scientific truth-seeking, that is, to grasp the laws of the development of the objective world; morality to seek good, that is, to achieve the ethical moral order; art for beauty, that freedom of necessity, the individual and the realization of social harmony. It can be said that "true, good and beautiful" is "beautiful." As a kind of spiritual production and life process, art is a social phenomenon that is far from material and economic foundation than culture and morality.

\section{ART QUALITY EDUCATION MANAGEMENT}

The management of art quality education mainly includes the administration of art quality education, the management of school art quality education and the management of social art quality education [5]. The three-arts quality education management influence each other, mutual restraint, together constitute a complete organic system.

\subsection{Connotation of art quality education management}

The quality education in colleges and universities shoulders the responsibility of cultivating and improving students' artistic aesthetic ability and cultural accomplishment, disseminating the outstanding national arts and culture of our country and the outstanding artistic achievements of foreign countries [6,7]. It is the main way and content for colleges and universities to carry out aesthetic education. Art quality education management in colleges and universities as a subsystem of art education management, in order to achieve the cultivation of students' artistic ability and artistic realm for the purpose of a control and regulation activities. Usually art quality education management in colleges and universities must take the importance and follow the art of quality education as the prerequisite. The management of art quality education in colleges and universities includes the management, objectives, mechanisms, principles, methods, processes, education, teachers and managers themselves in art quality education management in colleges and 
universities.

\subsection{The characteristics of art quality education management}

College art quality education management has its own management features. First, the participation of management of art quality education in colleges and universities. In the management of art quality education in colleges and universities, the management objects are mainly teachers and college students. They are not only the main participants of art quality education in colleges and universities, but also the main body of management of art quality education in colleges and universities. Teachers are not only the managers of art education, but also have different degrees of management. Students not only need to be educated and managed, but also need to constantly control and manage themselves in the process of learning art knowledge so as to make the students themselves correct The direction to progress. Therefore, art education in colleges and universities, not only with the teachers, managers are closely related to work, but also with the students self-management is closely related.

Second, the unity of art quality education management in colleges and universities. Colleges and universities are the places where educational activities are mainly carried out. In all aspects of management, educationrelated elements are contained, each of which is closely linked with education. The management of artistic quality education set by the management department of art quality education in colleges and universities must serve and obey the goal of art quality education and guide teachers and students through supervision and inspection.

Third, the art quality education and management in colleges and universities for a long time. The main task of art quality education in colleges and universities is to train college students to establish a correct aesthetic and artistic outlook, to have healthy and healthy morality, and to enhance their sensibility, appreciation, expression and creativity in beauty. However, the management of art quality education in colleges and universities should achieve the goal of art quality education. This process is very complicated. Because the cultivation of students' aesthetic ability cannot be taken in the form of assault or overtime, it can only be raised by improving the aesthetic ability of students through subtle and cumulative artistic education.

\section{ANALYSIS OF ART QUALITY EDUCATION MANAGEMENT}

\subsection{National management policies are not specific enough}

Although the state has issued a series of regulations on art education, the specific policies and regulations on art quality education in colleges and universities are not specific enough. Different types of colleges and universities, in the curriculum, teaching organization, activities and quality evaluation mechanism should be different. Although the requirements of the curriculum, teaching organization and evaluation mechanism are set out in the documents related to the art quality education in colleges and universities in the country, the specific content is not very clear and lack of operability, which leads to the implementation of the school is at a loss. Increase the difficulty of implementation.

Some local comprehensive universities in our country are mostly transformed by universities of science and engineering. The foundation of their own humanistic quality is relatively scarce. In order to cater to the general trend of reform, some humanities and arts faculties have simply been added without forming Improve the comprehensive university art and cultural atmosphere. Coupled with many of the school leaders who are science and engineering background, but also inevitably bring some of the old ideas and concepts for moral, political, cultural courses and students' professional skills more emphasis and strict requirements, but for art education courses and activities are not too Attention should be paid to the fact that art quality education in colleges and universities is an auxiliary link, thus neglecting art quality education in management systems and policies, and worsening its marginalization.

\subsection{Art education management agencies lacking}

The Ministry of Education once clearly stipulated that provincial and prefectural educational administrations should set up special institutions to manage the art quality education in schools and be provided with specialists to manage the art quality education in schools. The county-level administrative department of education should be equipped with full-time or part-time cadres responsible for the management of school art quality education. The school should have a school-level leadership responsible for the school's art quality education. Colleges and universities should set up artistic quality education committee or art quality education leading group. To further establish and improve provincial, prefectural and county tertiary research and teaching network, provincial and prefecture-level scientific research institutions should be equipped with full-time music art teaching and research staff, county-level inspection agencies with fulltime art disciplines to enhance the quality of education in schools in the region Teaching business guidance.

Although the state promulgated the document that local and university colleges and universities should set up specialized artistic quality education management agencies and clearly stipulate their functions, rights and responsibilities, due to the lack of attention of the leaders of the units, the institutions established eventually cannot exercise their own rights and work Cannot proceed smoothly. If some colleges and universities have set up art quality education departments, they all fail to perform their management functions and rights well. Their institutions are not effective, and their work is hard to carry out. The focus of university personnel training program is still on the students' professional skills.

\subsection{There are short-term behaviors in art quality education management}

From the current status of art quality education in colleges and universities, it can be seen that art quality education in colleges and universities lacks overall long-term planning and development goals. Art quality education is not scientific. The "Resolution" promulgated by the Central Committee of the Communist Party of China and the "Plan" issued by the Ministry of Education have long established the overall plan for the art quality education in higher learning institutions in the country and have subsequently promulgated a new development plan and given the role and significance of art quality education Defined. Most schools' art quality education programs are basically included in the humane quality education programs or general education programs.

Art education does not have a separate education program. The Academic Affairs Department's personnel training program only places requirements on credits for public elective courses and does not specify credits for public art electives. The school's talent training program for the art of quality education, a clear program, will determine the school's emphasis on art quality education basis. This depends first and foremost on the importance of school leaders and advanced educational concepts and regards art quality education as an important teaching content in schools. Therefore, relevant agencies of art quality education can truly implement their own functions as leaders make decisions And rights.

\subsection{Art quality education evaluation system is not perfect}

At present, there is no comprehensive assessment system for the management of artistic quality education in local comprehensive universities. As a result, the teacher's emphasis on the curriculum is not high, the lack of enthusiasm, student participation is not strong result, affecting the school's public art level. The art assessment system used in art-based education differs from the education evaluation system in other programs. For art quality education teaching effect of inspection and evaluation of the use of more measurement methods, is a quantitative analysis.

Art quality education assessment is a measure of value judgments, is a more ambiguous evaluation of ingredients, should not be a single knowledge evaluation. The teaching of art quality education curriculum is not only knowledge, but also spiritual content, is a combination of human imagination and reality. However, in the real education, the function of art quality education has not really been brought into play. The more students contact is the superficial theoretical knowledge of art. Many students choose elective courses, not to learn knowledge, but because public art teacher exams simple, easy to choose courses. As a result, the evaluation standard of public art curriculum is still at the level of basic knowledge, but there is no education of art quality education.

\section{ANALYSIS OF COUNTERMEASURES}

The improvement of art quality education in colleges and universities cannot be separated from the support of school management institutions. Schools should be the art of quality education in the overall development planning, the development of school art education specific development plan, establish an effective incentive and supervision mechanism.

\subsection{Art quality education into the overall quality of university} students in the evaluation

The Evaluation of College Students' Comprehensive Quality is an Important Measure for the Implementation of Quality Education in 
Chinese Universities. As art quality education is of great significance to enhancing the cultivation of qualified personnel and promoting the improvement of students' quality, it is suggested that colleges and universities should start as soon as possible the project of integrating art quality education into the overall quality evaluation of college students. Colleges and universities should be the student body and the Communist Youth League and other departments, departments, classes supplemented by the quality of education for art students to accept and participate in the practice of art-quality education to evaluate the situation. Put students in art quality education practice activities and art quality education elective courses credit into comprehensive evaluation, as one of the criteria for student semester awards; establish an effective reward supervision mechanism to ensure the normal, orderly and effective music education Promote and promote the overall quality of students' overall ability to enhance.

\subsection{To establish art quality education teaching and research}

At present, most colleges and universities in our province do not have a special teaching department of art quality education, making the theoretical research on teaching objectives, curriculum construction and evaluation system of art quality education in colleges and universities seriously lagged behind, becoming one of the important reasons that affect the development of art quality education in colleges and universities. Therefore, colleges and universities should establish art quality education teaching and research department, configure professional art teachers and a variety of professional activities and equipment.

Arts Quality Education Teaching and Research Section assumes the heavy responsibility of art elective courses in the whole school and is responsible for outline selection of elective courses such as arts quality education, selection and preparation of teaching materials, curriculum and academic teaching and research activities; is responsible for the guidance of art organizations and student art practice in schools; Lectures; the establishment of art exchanges and cooperation between colleges and universities; efforts to create a campus atmosphere of art, enrich campus cultural life, cultivate and improve college students aesthetic ability and cultural accomplishment, and promote the overall quality of college students.

\section{CONCLUSION}

Art quality education, as an important component of general higher education quality education, is not only an important way to carry out aesthetic education for college students, but also a fundamental requirement to promote the all-round development of moral, intellectual and physical education among college students. Art quality education is the core content of aesthetic education. It is an important way and means of aesthetic education. It is also an important component of quality education. It also plays an irreplaceable role in other education. Artistic quality education undertakes the task of opening people's perception, comprehension, creativity and imagination, and it is an education that makes people's inner feelings edify. Colleges and universities are places for training qualified personnel. In order to train qualified personnel who can adapt to the all-round development of our country's modernization construction, we should not only pay great attention to the education of students 'professional qualities, but also emphasize the cultivation of students' artistic accomplishments.

\section{ACKNOWLEDGMENTS}

This dissertation is a staged achievement of Heilongjiang Provincial Institute of Higher Education "13th Five-Year" research project of higher education "Comparative Study of Art Quality Education between China and Russia universities", project number: 16Z069.

\section{REFERENCES}

[1] Maen. 2000. Quality education of college students [M]. Xi'an Press.

[2] Xiuying, C. 2005. The comprehensive educational function of art education and its practice [J]. Yunmeng Journal, 6 (2).

[3] Yaling, C. 2011. Analysis and reflection on the status of public art education in colleges and universities [J]. Modern Education Science, 5 (2).

[4] Zhengming, C. 2008. The comprehensive university of public art education status quo, problems and countermeasures [D]. Southwest University.

[5] Zhipu, H. 2011. On the characteristics of art education [J]. Journal of Hubei University (Philosophy and Social Sciences Edition), 3 (2).

[6] Xuxiao, W. 2012. China's public art education in the status quo and development trends [M] - Shanghai : Oriental Press, 10 (2), 77.

[7] Dechong, L., Feng, D. 2011. Art quality education in colleges and universities of the status quo and Countermeasures [J]. Popular Literature. 